Int. J. Electrochem. Sci., 12 (2017) 10359 - 10368

International Journal of

ELECTROCHEMICAL

SCIENCE

www.electrochemsci.org

\title{
An Electrochemical Aptasensor for Thrombin Based on a Novel Polyamidoamine Dendrimer-Streptavidin Supramolecular Architecture
}

\author{
N. Soda ${ }^{1}$ and $O$. A. Arotiba ${ }^{1,2, *}$ \\ ${ }^{1}$ Department of Applied Chemistry, University of Johannesburg, South Africa \\ ${ }^{2}$ Centre for Nanomaterials Science Research, University of Johannesburg, South Africa \\ *E-mail: oarotiba@uj.ac.za
}

doi: $10.20964 / 2017.11 .10$

Received: 11 June 2017 / Accepted: 23 August 2017 / Published: 12 October 2017

This work reports the development of an electrochemical aptasensor for thrombin based on a polyamidoamine dendrimer-streptavidin supramolecular architecture prepared by the cyclic voltammetric electrodeposition of polyamidoamine dendrimer (PAMAM) followed by the drop coating of streptavidin on a glassy carbon electrode. Biotinylated aptamer probe was immobilised on the platform through biotin-streptavidin interaction. The aptasensor preparation was monitored with voltammetry and electrochemical impedance spectroscopy. The biosensor response to thrombin was evaluated with square wave voltammetry (in phosphate buffer solution and in ferro/ferric cyanide probe) and electrochemical impedance spectroscopy. Linear responses in the concentration range between $1-200 \mathrm{ng} \mathrm{mL}^{-1}$ and detection limit in the sub $0.02 \mathrm{ng} \mathrm{mL}^{-1}$ (defined as $\left(C_{L}=3 S_{B} / \mathrm{m}\right)$ were calculated. The selectivity of the aptasensor was evaluated using interfering proteins such as bovine serum albumin (BSA), lysozyme and haemoglobin. The relative response obtained shows insignificant effect from the interfering proteins with BSA, lysozyme and haemoglobin having a relative response of $9.2 \%, 8.7 \%$ and $7.6 \%$ respectively.

Keywords: Biosensor; thrombin; polyamidoamine dendrimer; streptavidin; supramolecular.

\section{$\underline{\text { FULL TEXT }}$}

(C) 2017 The Authors. Published by ESG (www.electrochemsci.org). This article is an open access article distributed under the terms and conditions of the Creative Commons Attribution license (http://creativecommons.org/licenses/by/4.0/). 